\title{
CSR Implications: Comparative Analysis of Indian Companies with MNCs
}

\author{
Effulgence \\ Vol. 16 No. 1 \\ January - June, 2018 \\ Rukmini Devi Institute of Advanced Studies \\ E-mail : effulgence@rdias.ac.in, Website : www.rdias.ac.in \\ http:/ / effulgence.rdias.ac.in/user/default.aspx \\ https://dx.doi.org/10.33601/effulgence.rdias/v16/i1/2018/1-13
}

\section{Manisha Rani}

\begin{abstract}
Purpose - The purpose of this paper is to explore various different areas of CSR covered by the companies in India and to have a comparative analysis of such implications of Indian companies and MNCs.

Design/methodology/approach - The sample for the present study consisted of 30 companies including 15 Indian companies and 15 MNCs of different countries working in India in various industries. The data thus generated was analyzed with the help of non-parametric test and factor analysis.

Findings - The study finds that there is a not any difference in CSR practices of Indian companies and MNCs and that is in terms of focused areas of CSR. Companies are adopting CSR practices of environmental marketing, sustainable development, rural empowerment, local community support, and social empowerment.
\end{abstract}

Keywords: CSR principles, CSR activities, Social responsibilities, Environmental marketing.

\section{INTRODUCTION}

$\mathrm{T}$ he concept of corporate social responsibility is not new to India though. It has been a tradition in a number of organizations, particularly familybased firms with a strong community ethos. Historically it has been a significant influence, impacting on business, government and society relationships. It has been defined in a number of ultimate ways and to a big extent the discussions about 'what it is' have been confused by the variety of normal perspectives adopted the concept of CSR in India is not new. The process though acclaimed recently, has been followed since ancient times albeit informally. The concept of helping the poor and disadvantaged was cited in much of the ancient literature. The idea was also supported by several religions where it has been intertwined with religious laws. Hindus follow the principle of -Dhramada or getting salvation -Moksh and forms an integral part of almost all Hindu rituals. Similarly in Sikhism, provision of free - Lunger - food and

\section{Research Scholar, Department of Commerce, B.M.U. Rohtak, manimehta297@rediffmail.com}


shelter in the -Gurudwaras and also a provision of $10 \%$ of income donate to Gurudwaras named 'Daswant' has been another illustration of institutionalized philanthropy (Sanjay, 2008). -Zakaat, followed by Muslims, is donation from one's earnings which is specifically given to the poor and disadvantaged. In the global context, the recent history goes back to the seventeenth century when in 1790s, England witnessed the first large scale consumer boycott over the issue of slave harvested sugar which finally forced importer to have freelabor sourcing. In India, in the pre independence era, the businesses which pioneered industrialization along with strongly fighting for independence also followed the (CSR) idea. They put the idea into action by setting up charitable foundations, educational and healthcare institutions, and trusts for community development. The donations either monetary or otherwise were sporadic activities of charity or philanthropy that were taken out of homely or personal savings which neither belonged to the shareholders or partners nor did it constitute an integral part of business. The term CSR itself came in to common use in the early 1970s although it was seldom abbreviated. By late 1990s, the concept was full recognized; people and institutions across all sections of society started supporting it. This can be corroborated by the fact that while in 1977 less than half of the Fortune 500 firms even represented CSR in their annual reports.

Researchers have shown that knowledge of companies' CSR activities positively affects both attitude and purchase intent of consumers (Wigley, 2008). Corporate social contribution and local community contribution affect consumers' purchase intention (Lee and Shin, 2010). It is a proven fact now that CSR activities also have bearing on the image of the company. CSR activities enhance company's image when consumers make attribute planned motives, are ineffective when sincerity of motives is ambiguous, and hurt the company's image when motives are perceived as insincere (Yoon et al., 2006). Adopting CSR allows companies to build brand values and costs of building brand value through social responsibility initiatives are usually cheaper than trying the same effect through advertising and public relations (Joshi and Gao, 2009).

\section{REVIEW OF LITERATURE}

Some researchers have studied the CSR activities of companies in different countries across various industries and have given observations on the basis of their results. Jones et al. (2007) found that some of the top ten retailers claimed a long-standing commitment to managing the environmental impacts of their operations. These impacts included energy consumption and emissions, raw material usage, water consumption, waste management, packaging, recycling, the use of chemicals, and genetically modified food ingredients. Silberhorn and Warren (2007) also observed that largest corporations are projecting CSR as a comprehensive sustainable business strategy, based on transparency, accountability and responsiveness, which recognizes the business-society interdependence and constantly evolves in interactions between the company and its increasingly global environment. Samy et al. (2010) revealed that UK companies tended to disclose the positive impacts they made on the environment, which has to do with environmental issues. This included environmental pollution, waste disposal, gas emissions, and other related environmental issues. Schneider et al. (2010) benchmarked the evolution of reported sustainability activity in the pharmaceutical sector and found that sustainability related activity has increased in breadth and depth, but activity is now being shifted toward CSR, which is reflective of corporate need to satisfy public sentiment. Planken et al. (2010) revealed that Indian corporate pursue a primarily philanthropic platform with a focus on community development projects. However, it was also indicated that Indian consumers may not value philanthropic CSR as highly as other CSR initiatives and that this may in turn influence their attitude to different marketing communication strategies. Thus, in the light of above findings, observation made by Sachdeva (2010) seems to be absolutely right that CSR is slowly 
moving away from charity and dependence and is starting to build on empowerment and partnership.

Some studies highlight issues related to CSR of MNCs in their host countries. Prout (2006) developed the self-interested, business rationale for the export of socially responsible business behavior by multinational firms to developing economies. It was argued that corporations typically have a selfinterested approach to adopting CSR values; either for marketing purposes, or to sustain acceptance among socially conscious investors, consumers, and competitors. Eweje (2007) found that expectations of host communities in the Niger Delta for CSR/community development initiatives are greater. The companies, on the other hand, have embraced development initiatives primarily in order to demonstrate that they are socially responsible. Yang and Rivers (2009) proposed that MNCs' subsidiaries will be likely to adapt to local practices to legitimize themselves, if their parent companies suffer major legitimacy problems at home or abroad. However, MNCs' subsidiaries will be, if they are strongly annexed to their parent companies and the benefit to gain internal legitimacy outweighs external legitimacy concluded that The corporate codes of conduct of MNCs operating in Nigeria, to a large extent, reflect the characteristics of their home countries' model of capitalism, respectively, albeit with certain degree of modification. Amaeshi and Amao (2009). Kolk and Lenfant (2009) observed that MNCs face large CSR dilemmas, related to the contribution they can (or cannot) give in the different setting compared to their home countries as well as their attitude vis-a` ongoing conflicts. Tan (2009) revealed that discrepancies exist in how MNCs perform in CSR in home countries versus in host countries. Adewuyi and Olowookere (2010) found that, although the proportion of resources committed to CSR is small, CSR expenditure rises with the firm's sales (in host communities)

\section{RESEARCH PROBLEM}

Business has different stakeholders which include customers, employees, suppliers, government, environment, and society at large.CSR is multidimensional in nature. Given this, there is a wide range of socially responsible activities followed by the business units. Within the company, socially responsible practices primarily include caring for human resources i.e. the employees and workers, their health and safety. They also cover environmentally responsible practices relating to environment protection, waste management, and natural resources, etc. Externally, companies can contribute by enhancing education, health, social welfare, etc. Companies undertaking such activities have to make sure that these programs fit in their business policies and by doing this their efficiency would come to a level. Now the question arises, in what way and to what extent, these CSR activities will affect their stakeholders and business as well. While answering these questions different CSR policies are framed by companies. Literature review shows that there exist some prior studies (Planken et al., 2010 and Sachdeva, 2010) to explore CSR activities of companies in India and most of them indicate positive trends in this area. Many authors have also attempted to investigate the role of MNCs in the field of CSR, with special reference to their host economies, generally developing ones (Prout, 2006; Eweje, 2007; Yang and Rivers, 2009; Amaeshi and Amao, 2009; Kolk and Lenfant, 2009; Tan, 2009; Adewuyi and Olowookere, 2010). The available knowledge in this area formed the background for the present study. India being a favorite destination, hosts a large number of MNCs from all over the world, which are giving a tough competition to their Indian counterparts, in almost every field, including CSR. So a need was felt to have a comparison of CSR practices of Indian companies and MNCs. Thus, the research problem has been stated as: "is there any difference between the CSR practices followed by MNCs and their counterparts Indian companies ".

\section{OBJECTIVES}

1. To compare the CSR implications of Indian companies and MNCs in India.

2. To find the interrelationship between variables. 


\section{METHODOLOGY}

Out of the top 100 companies including MNCs working in India, 30 were selected randomly (using systematic random sampling technique) from seven industries:-

1. Automobiles

2. IT

3. Cement \& Cement products

4. Telecommunication

5. Banking \& Finance

6. Energy \& Power

7. FMCG

30 companies (sample size for the present study) including 15 Indian companies and 15 MNCs provided the required information for 2015-16. In this regard help was taken from www.fundoodata.com (Database of companies' names, address, etc.) and www.mca.gov.in (official web site of Ministry of Corporate Affairs). Theoretical framework was developed from the secondary data, comprising of the published literature. In line with the research problem, secondary data was generated by means of annual reports. A detailed review of literature and information available on web sites of different companies were of great help for this purpose. The study contained 13 CSR activities (Table 1). These activities were assigned code V1, V2, V3.to V13 for identification. First, the data was tested for "Homogeneity of variances". Levene's test was applied and it was found that variances are equal for most of the variables. Then data was subjected to the test for normality, results of which revealed that data is not normally distributed. Because of the failure of normality test, it was decided to apply nonparametric test (Instead of ANOVA or t-test) to find out the significance of variances in CSR activities being carried out by Indian companies and MNCs. Thus, Mann-Whitney U Test was found to be most suitable. Further, Factor Analysis has been applied to find out thrust areas of CSR focused by Indian companies and MNCs working in India.

\section{FINDINGS}

Table 1: Variables

\begin{tabular}{|l|c|}
\hline CSR Activities & Variables \\
\hline Eradicating Hunger Poverty \& Malnutrition & V1 \\
\hline Swachh Bharat Abhiyaan, Sanitation \& Drinking Water & V3 \\
\hline Promoting Education \& Scholarship To Minorities & V4 \\
\hline Employment Enhancing Vocational Skills & V5 \\
\hline Women Empowerment & V6 \\
\hline Social Empowerment \& Benefit To Armed Forces & V7 \\
\hline Tree Plantation Drives & V8 \\
\hline Preventive Healthcare Programs & V9 \\
\hline Preserving Natural Resources & V10 \\
\hline Promoting Sports & V11 \\
\hline Rural development projects & V12 \\
\hline Protection of national heritage \& art & V13 \\
\hline Disaster relief \& slum area development & \\
\hline
\end{tabular}


Table 2: Summery of Mann-Whitney U Test

\begin{tabular}{|c|c|c|c|c|c|}
\hline Variables & $\begin{array}{c}\text { Mann-Whitney } \\
\text { U }\end{array}$ & Wilcoxon W & Z & $\begin{array}{l}\text { Asymp. Sig. (2- } \\
\text { tailed)P }\end{array}$ & $\begin{array}{l}\text { Exact Sig. } \\
\text { [2*(1-tailed } \\
\text { Sig. })]\end{array}$ \\
\hline Eradicating Hunger Poverty \& Malnutrition (V1) & 66.500 & 186.500 & -2.274 & .023 & .056 \\
\hline Swachh Bharat Abhiyaan,Sanitation \& Drinking Water (V2) & 111.000 & 231.000 & -.063 & .950 & .967 \\
\hline Promoting Education \& Scholarship To Minorities (V3) & 87.000 & 207.000 & -1.058 & .290 & .305 \\
\hline Employment Enhancing Vocational Skills (V4) & 101.000 & 221.000 & -.479 & .632 & .653 \\
\hline Women Empowerment (V5) & 71.000 & 191.000 & -1.944 & .052 & .089 \\
\hline Social Empowerment \& Benefit To Armed Forces (V6) & 103.000 & 223.000 & -.445 & .656 & .713 \\
\hline Tree Plantation Drives (V7) & 87.000 & 207.000 & -1.427 & .154 & .305 \\
\hline Preventive Healthcare Programs (V8) & 108.000 & 228.000 & -.187 & .851 & .870 \\
\hline Preserving Natural Resources (V9) & 92.000 & 212.000 & -.856 & .392 & .412 \\
\hline Promoting Sports (V10) & 86.500 & 206.500 & -1.218 & .223 & .285 \\
\hline Rural Development Projects (V11) & 106.000 & 226.000 & -.275 & .784 & .806 \\
\hline Protection Of National Heritage \& Art (V12) & 106.000 & 226.000 & -.312 & .755 & .806 \\
\hline Disaster Relief \& Slum Area Development (V13) & 92.500 & 212.500 & -.989 & .323 & .412 \\
\hline \multicolumn{6}{|l|}{ a. Not corrected for ties. } \\
\hline b. Grouping Variable: Companies & & & & & \\
\hline
\end{tabular}

\section{Results of Mann-Whitney U Test}

Results of Mann-Whitney U Test (Table 2) reveal that there is significant difference in the CSR activity of Eradicating Hunger Poverty \& Malnutrition, the Z values being $-2.214(p=0: 023)$. In this activity, the mean rank (Table III) accorded by MNCs (18.57) is more than that of Indian Companies (12.43), and $\mathrm{p}$ value is less than 0.05 . It indicates that MNCs are more involved in this activity of Eradicating Hunger
Poverty \& Malnutrition as compared to Indian Companies. As far as the other CSR activities are concerned, the difference between mean ranks is not found statistically significant as reflected by their non-significant $Z$ values. Thus, it can be inferred that MNCs and Indian companies are involved in all these 13 CSR activities to the same spirit.

Table 3 - Descriptive statistics of CSR activities (for Mann Whitney U Test)

Table 3: Rank sum test

\begin{tabular}{|c|c|c|c|c|}
\hline CSR Activities & Companies & $\mathrm{N}$ & Mean Rank & Sum of Ranks \\
\hline \multirow{3}{*}{ Eradicating hunger poverty \& malnutrition (V1) } & Indian & 15 & 12.43 & 186.50 \\
\hline & MNCs & 15 & 18.57 & 278.50 \\
\hline & Total & 30 & & \\
\hline \multirow{3}{*}{ Swachh bharat abhiyaan, sanitation \& drinking water (V2) } & Indian & 15 & 15.40 & 231.00 \\
\hline & MNCs & 15 & 15.60 & 234.00 \\
\hline & Total & 30 & & \\
\hline \multirow{3}{*}{ Promoting education \& scholarship to minorities (V3) } & Indian & 15 & 13.80 & 207.00 \\
\hline & MNCs & 15 & 17.20 & 258.00 \\
\hline & Total & 30 & & \\
\hline \multirow{3}{*}{ Employment enhancing vocational skills (V4) } & Indian & 15 & 14.73 & 221.00 \\
\hline & MNCs & 15 & 16.27 & 244.00 \\
\hline & Total & 30 & & \\
\hline
\end{tabular}




\begin{tabular}{|c|c|c|c|c|}
\hline \multirow{3}{*}{ Women empowerment (V5) } & Indian & 15 & 12.73 & 191.00 \\
\hline & MNCs & 15 & 18.27 & 274.00 \\
\hline & Total & 30 & & \\
\hline \multirow{3}{*}{ Social empowerment \& benefit to armed forces (V6) } & Indian & 15 & 14.87 & 223.00 \\
\hline & MNCs & 15 & 16.13 & 242.00 \\
\hline & Total & 30 & & \\
\hline \multirow{3}{*}{ Tree plantation drives (V7) } & Indian & 15 & 13.80 & 207.00 \\
\hline & MNCs & 15 & 17.20 & 258.00 \\
\hline & Total & 30 & & \\
\hline \multirow{3}{*}{ Preventive healthcare programs (V8) } & Indian & 15 & 15.80 & 237.00 \\
\hline & MNCs & 15 & 15.20 & 228.00 \\
\hline & Total & 30 & & \\
\hline \multirow{3}{*}{ Preserving natural resources (V9) } & Indian & 15 & 14.13 & 212.00 \\
\hline & MNCs & 15 & 16.87 & 253.00 \\
\hline & Total & 30 & & \\
\hline \multirow{3}{*}{ Promoting sports (V10) } & Indian & 15 & 17.23 & 258.50 \\
\hline & MNCs & 15 & 13.77 & 206.50 \\
\hline & Total & 30 & & \\
\hline \multirow{3}{*}{ Rural development projects (V11) } & Indian & 15 & 15.07 & 226.00 \\
\hline & MNCs & 15 & 15.93 & 239.00 \\
\hline & Total & 30 & & \\
\hline \multirow{3}{*}{ Protection of national heritage \& art (V12) } & Indian & 15 & 15.07 & 226.00 \\
\hline & MNCs & 15 & 15.93 & 239.00 \\
\hline & Total & 30 & & \\
\hline \multirow{3}{*}{ Disaster relief \& slum area development (V13) } & Indian & 15 & 14.17 & 212.50 \\
\hline & MNCs & 15 & 16.83 & 252.50 \\
\hline & Total & 30 & & \\
\hline
\end{tabular}

\section{Results of Factor Analysis (Indian Companies)}

Data pertaining to Indian companies was subjected to factor analysis using principal component method resulting into extraction of four factors accounting for a total variance of 87.342.The communalities (h2) range from 0.562 to 0.981 (Table 4). The items with factor loading 0.5 or above are retained (Quazi and O'Brien, 2000). Each one of four factors represents CSR practices of Indian companies. Following is the detailed explanations of all these factors (see Table 5).

Factor 1. Environmental Marketing - CSR activities pertaining to environment namely Swachh bharat abhiyaan, sanitation \& drinking water, Preserving natural resources extracted, with very high positive loading on this factor. It shows that Indian companies give due importance to environment protection which may help the country to tackle the growing menace of the global warming. Swachh
Bharat Abhiyaan, Sanitation \& Drinking Water help the society to have clean environment, recycling of waste before its disposal helps in reducing the pollution and Preserving natural resources leads the environment protection. Apart from these, Promoting education is also make contribution in Environment sustainability through knowledge of environment conservation. Keeping in mind the composition of this factor, it has been named as "Environmental marketing".

Factor 2. Social Empowerment - Empowerment emerged as another important CSR practices comprising of Women empowerment, Disaster relief \& slum area development, Protection of national heritage \& art. In India a great need of women empowerment including gender equality because every time they exploited by society. This factor addresses the efforts of Indian companies towards the betterment of women and weaker sections of society so that they can be brought back to the main 
stream. In developing countries like India, the above stated section of society is underprivileged and need assistance from other institutions, besides this Indian companies seem to be discharging this responsibility distinctively, thus helping the Government to uplift the needy section of society with slum area development. Companies also make contribution in National heritage \& art protection.
Factor 3. Sustainable Development - Employment enhancing vocational skills, Preventive healthcare programs these are prominent activities of Sustainable development. Generation of employment is being done by Employment enhancing vocational skills, companies and government intiating the Industrial Trainig Institutes (I.T.I).. Generation of employment highly loaded on this factor shows the companies' efforts towards the inclusion of challenges into the main stream.

Table 4: Rotated Component Matrixa (Indian)

\begin{tabular}{|c|c|c|c|c|c|c|}
\hline & \multicolumn{5}{|c|}{ Component } & \multirow[b]{2}{*}{$h^{2}$} \\
\hline & 1 & 2 & 3 & 4 & 5 & \\
\hline Swachh bharat abhiyaan, sanitation \& drinking water (V2) & .961 & .070 & .017 & .002 & .193 & .909 \\
\hline Promoting education \& scholarship to minorities (V3) & .917 & -.040 & .261 & .152 & -.023 & .965 \\
\hline Preserving natural resources (V9) & .810 & -.217 & 190 & .017 & -.325 & .934 \\
\hline Disaster relief \& slum area development (V13) & -.165 & .912 & .279 & -.038 & -.186 & .937 \\
\hline Women empowerment (V5) & -.137 & .895 & -.129 & -.074 & -.122 & .858 \\
\hline Protection of national heritage \& art (V12) & .548 & .782 & .035 & .097 & .113 & .786 \\
\hline Employment enhancing vocational skills (V4) & .069 & .050 & .956 & .040 & .119 & .654 \\
\hline Preventive healthcare programs (V8) & .397 & .136 & .822 & -.100 & .147 & .883 \\
\hline Eradicating hunger poverty \& malnutrition (V1) & -.099 & .047 & -.204 & .923 & .055 & .846 \\
\hline Promoting sports (V10) & .300 & -.110 & .262 & .861 & -.210 & .957 \\
\hline Rural development projects (V11) & .190 & -.157 & .115 & .063 & .800 & .718 \\
\hline Tree plantation drives (V7) & -.253 & -.208 & .333 & -.152 & 642 & .935 \\
\hline Social empowerment \& benefit to armed forces (V6) & .169 & -.281 & .473 & .348 & -.578 & .972 \\
\hline $\begin{array}{l}\text { Extraction Method: Principal Component Analysis. } \\
\text { Rotation Method: Varimax with Kaiser Normalization. }\end{array}$ & & & & & & \\
\hline
\end{tabular}

Table 5: Details of extracted factors for Indian Companies

\begin{tabular}{|l|l|c|}
\hline Sr. No. & Activities & Loading \\
\hline Factor $\mathbf{1}$ & Environmental Marketing & \\
\hline 1 & Swachh Bharat Abhiyaan, Sanitation \& Drinking Water (V2) & 0.961 \\
\hline 2 & Promoting Education \& Scholarship To Minorities (V3) & 0.917 \\
\hline 3 & Preserving Natural Resources (V9) & 0.810 \\
\hline Factor 2 & Social Empowerment & 0.912 \\
\hline 1 & Disaster Relief \& Slum Area Development (V13) & 0.895 \\
\hline 2 & Women Empowerment (V5) & 0.782 \\
\hline 3 & Protection Of National Heritage \& Art (V12) & \\
\hline
\end{tabular}




\begin{tabular}{|l|l|c|}
\hline Factor 3 & Sustainable Development & \\
\hline 1 & Employment Enhancing Vocational Skills (V4) & 0.956 \\
\hline 2 & Preventive Healthcare Programs (V8) & 0.822 \\
\hline Factor $\mathbf{4}$ & Local Community Support & \\
\hline 1 & Eradicating Hunger Poverty \& Malnutrition (V1) & 0.923 \\
\hline 2 & Promoting Sports (V10) & 0.861 \\
\hline Factor $\mathbf{5}$ & Rural Empowerment & 0.800 \\
\hline 1 & Rural Development Projects (V11) & 0.642 \\
\hline 2 & Tree Plantation Drives (V7) & 0.578 \\
\hline 3 & Social Empowerment \& Benefit To Armed Forces (V6) & \\
\hline
\end{tabular}

Factor 4. Local Community Support - In this factor Eradicating hunger poverty \& malnutrition, Promoting sports with high positive loading (Eradicating hunger poverty \& malnutrition) on this factor.. It shows that Indian companies give due importance to Local community which may help the country to tackle the problem of hunger \& poverty. India is a country of sports, so sponsorship to sport event is regularly contributed.

Factor 5. Rural Empowerment - In this factor, Rural development projects, Tree plantation drives, Social empowerment \& benefit to armed forces are extracted. It shows that Indian companies give due importance to rural emp. which may help the country to tackle the problem of rural areas. It saves the livestock. Here in social empowerment - support old age people, welfare of differently abled, help to mentally challenge people are included. In India there is many problems for old age people like shelter and food facilities Indian companies supporting them with named vridh ashrams and also make donation for differently abled \& mentally challenge people in the form of education and health related facilities. Although benefit to armed forces is not a regular activity, still contribution attempted with 1 Rs. deposit account, appealed by film star Mr. Akshey khanna and P.M. Mr Narender Modi. India is a country of sports, so sponsorship to sport event is regularly contributed. Indian companies also make contribution in Tree plantation drives.

\section{Results of Factor Analysis (MNCs)}

MNCs. In case of MNCs four factors were extracted (Table 7), whose Eigen value exceeded 1.00. A total variance of 84.792 is accounted for by these four factors. The communalities (h2) are ranging from 0.562 to 0.981 (Table 6).

Factor 1. Sustainable Development - Women Empowerment, Tree Plantation Drives, Rural development projects, Preserving Natural Resources, Eradicating Hunger Poverty \& Malnutrition all these activities included in this factor. Women Empowerment with high factor loading. In India a great need of women empowerment including gender equality because every time they were exploited by society. This factor addresses the efforts of MNCs towards the betterment of women and weaker sections of society so that they can be brought back to the main stream. In developing countries like India, the above stated section of society is underprivileged and need assistance from other institutions, besides this MNCs seem to be discharging this responsibility distinctively. The positive loadings on this factor highlight that the variables above stated, share most of their variances, hence, co-vary to each other. Tree plantation drives help the society to have clean environment. Preserving natural resources helps in reducing the pollution. 
Table 6: Rotated Component Matrixa (MNCs)

\begin{tabular}{|c|c|c|c|c|c|}
\hline & \multicolumn{4}{|c|}{ Component } & \multirow[b]{2}{*}{$\mathrm{h}^{2}$} \\
\hline & 1 & 2 & 3 & 4 & \\
\hline Women Empowerment (V5) & .981 & -.109 & -.016 & .083 & .847 \\
\hline Tree Plantation Drives (V7) & .959 & .219 & -.024 & .022 & .562 \\
\hline Rural Development Projects (V11) & .914 & .260 & .244 & .059 & .963 \\
\hline Preserving Natural Resources (V9) & .903 & .081 & .134 & .002 & .927 \\
\hline Eradicating Hunger Poverty \& Malnutrition (V1) & .687 & .584 & -.054 & -.173 & .981 \\
\hline Promoting Education \& Scholarship To Minorities (V3) & .220 & .956 & -.005 & .001 & .591 \\
\hline Preventive Healthcare Programs (V8) & .221 & .928 & .211 & -.110 & .969 \\
\hline Promoting Sports (V10) & .100 & .763 & .598 & -.042 & .967 \\
\hline Disaster Relief \& Slum Area Development (V13) & -.033 & .717 & -.292 & .208 & .839 \\
\hline Social Empowerment \& Benefit To Armed Forces (V6) & .019 & .683 & -.183 & -.301 & .952 \\
\hline Protection Of National Heritage \& Art (V12) & $-3.943 E-5$ & -.014 & .901 & -.061 & .965 \\
\hline Swachh Bharat Abhiyaan, Sanitation \& Drinking Water (V2) & .384 & -.213 & .531 & .296 & .815 \\
\hline Employment Enhancing Vocational Skills (V4) & .044 & -.063 & -.006 & .960 & .644 \\
\hline $\begin{array}{l}\text { Extraction Method: Principal Component Analysis. } \\
\text { Rotation Method: Varimax with Kaiser Normalization. }\end{array}$ & & & & & \\
\hline
\end{tabular}

Factor 2. Local Community Support - Promoting Education, Preventive Healthcare Programs, Promoting Sports, Disaster relief \& slum area development, Social Empowerment \& Benefit To Armed Forces. Empowerment emerged important CSR practices comprising of Preventive healthcare Programs, Promoting education \& scholarship to minorities, Promoting sports, Social empowerment \& benefit to armed forces. Health care Programs include improving maternal health with reducing child mortality. MNCs are taking much initiatives for the same. Next activity in which corporations attempt challenging job i.e. scholarship to SC, BC, ST and educational facilitates to all. with sports promotion it will lead in these activities. Corporations also make contribution in development of armed forces and defense mechanism. All these variables share most of their variance, hence, covary. Thus, it can be concluded that MNCs are highly involved in Social Empowerment by addressing the above mentioned activities.
Factor 3. Environmental Marketing - Protection of national heritage \& art, Swachh Bharat Abhiyaan, Sanitation \& Drinking Water. Protection of national monuments and amusements can have a long lasting positive impact on the company's profitability and can enhance its reputation among nationwide. MNCs are also making efforts to be ethical in their day to day business activities by paying attention toward Swachh Bharat Abhiyaan, Sanitation \& Drinking Water thereby adhering to the development principles of CSR

Factor 4. Social Empowerment - Employment enhancing vocational skills are the only one activity which is include in this factor, not sharing of variance with others. MNCs gives vocational training to students and workers to increase the employment or entrepreneurship development. With very high positive factor loading it leads to the development of society 
Table 7: Details of extracted factors for MNCs

\begin{tabular}{|l|l|c|}
\hline Sr. No. & Activities & Loading \\
\hline Factor 1 & Sustainable Development & \\
\hline 1 & Women Empowerment (V5) & 0.981 \\
\hline 2 & Tree Plantation Drives (V7) & 0.959 \\
\hline 3 & Rural Development Projects (V11) & 0.914 \\
\hline 4 & Preserving Natural Resources (V9) & 0.903 \\
\hline 5 & Eradicating Hunger Poverty \& Malnutrition (V1) & 0.687 \\
\hline Factor 2 & Local Community Support & 0.956 \\
\hline 1 & Promoting Education \& Scholarship To Minorities (V3) & 0.928 \\
\hline 2 & Preventive Healthcare Programs (V8) & 0.763 \\
\hline 3 & Promoting Sports (V10) & 0.717 \\
\hline 4 & Disaster Relief \& Slum Area Development (V13) & 0.683 \\
\hline 5 & Social Empowerment \& Benefit To Armed Forces (V6) & 0.901 \\
\hline Factor 3 & Environmental Marketing & \\
\hline 1 & Protection Of National Heritage \& Art (V12) & \\
\hline 2 & Swachh Bharat Abhiyaan, Sanitation \& Drinking Water (V2) & \\
\hline Factor 4 & Social Empowerment & \\
\hline 1 & Employment Enhancing Vocational Skills (V4) & \\
\hline & & \\
\hline & & \\
\hline & & \\
\hline & & \\
\hline
\end{tabular}

\section{DISCUSSION}

The findings of the present study reveal the kinds of CSR practices being followed by Indian companies and MNCs. The results highlight the significant difference in discharging social responsibilities of Eradicating Hunger Poverty \& Malnutrition between MNCs and Indian companies. Involvement of MNCs in these CSR activities is more as reflected by high mean score, whereas in rest of CSR activities there is no significant difference, hence are discharge with the same spirit by Indian companies and MNCs.
As far as the Indian companies are concerned, CSR practices of environmental marketing' got the priority, indicating thereby their responsiveness towards the environmental issues, whereas it is at second place in case of MNCs. Environmental marketing involve green activities mainly tree plantation, and recycling of waste, etc. depicting companies' concern towards environment protection. The environmental marketing practices is in conformity with Jones et al. (2007) who reported the long standing commitment of big companies to manage the environmental impact of their operation. 
Another CSR practice of "sustainable development" indicates the adherence of companies to CSR Principles. It involves activities like pollution control, recycling of wastes, preserving natural resources and quality control, etc. These activities undertaken by the companies will not only ensure the development of the society but also the long survival of the business. This factor has got Third place for Indian companies whereas first place for MNCs. In the back drop of the global warming, when the whole world is trying to find the solution to the climate change, corporate' commitment to pollution control is something very pleasant. Quality control and recycling of waste products is equally beneficial for the society as well as for the business to achieve sustainability. These findings are supported by Rondinelli and Berry (2000) who reported that large multinationals can be powerful forces for achieving sustainable development objectives.

In tune with these findings, the present study also highlights companies' concern for social problems and their efforts to solve them. Narwal (2007), who reported the involvement of Indian banking industry in the development of social infrastructure also support the findings of present study. This factor is common among both the groups, though it is at third place for Indian companies and first priority for MNCs depicting thereby MNCs' eagerness to help the local community in solving their social problems which may enhance their reputation among stakeholders. Indian companies and MNCs follow other principles of CSR. Ako et al. (2009) observed that companies operating in developing societies have a responsibility to contribute to the overall development of their host communities in partnership with government institutions and NGOs'

\section{SCOPE FOR FURTHER RESEARCH}

The present study gives an idea of CSR orientation of companies of Indian origin and MNCs working in India and any difference there. An industry specific research can be conducted to know the CSR involvement of corporate in particular industry/sector. A comparison of CSR practices of companies across industries can also be done. Another possible area for further research is comparison of CSR practices of MNCs across the countries/regions/continents of the world. Financial performance can be measured of highest ranking companies. A future research can also be conducted to know whether CSR can be used as a tool of strategic advantage for corporate. This will help the MNCs to formulate better CSR strategies. Impact of socially responsible behavior on corporate' financial performance may also be examined. To know the state and trends of CSR disclosures of MNCs in India is another possible area of future research.

Conclusion Environment degradation, global warming, and climate change are some of the burning global issues these days. These are getting the attention of corporate community not only in India but also worldwide. Since industry is seen as one of the major causes behind these problems, the efforts of companies aiming at sustainable development and environmental marketing is a welcome step, which will have a long lasting positive contribution towards the protection of environment and preservation of the natural resources. Companies are supporting local community and making efforts to solve their problems. Companies are also adhering to the principles of CSR namely, transparency, accountability, and sustainability. Moreover, these companies are discharging CSR by empowering the needy section of the society, thereby extending help to the Government to raise the standard of living. Though, cleanliness campaigns, ethical business practices, social audit, and women empowerment are some issues where local companies are more sensitive compared with the MNCs. Thus, it may be concluded that there is no major difference in CSR practices of MNCs and Indian companies as MNCs are adhering to the prevailing practices in host countries. These revelations may usher CSR revolution in India. 


\section{REFERENCES}

1) Adewuyi, A.O. and Olowookere, A.E. (2010), "Nigerian polluter: the West African Portland Cement (WAPCO) Nigerian PLC's case", Social Responsibility Journal, Vol. 6 No. 1, pp. 108-125.

2) Ako, R.T., Obokoh, L.O. and Okonmah, P. (2009), "Forging peaceful relationships between oil-companies and host-communities in Nigeria's delta region: a stakeholder's perspective to corporate social responsibility", Journal of Enterprising Communities: People and Places in the Global Economy, Vol. 3 No. 2, pp. 205-216.

3) Alon, I., Lattemann, C., Fetscherin, M., Li, S. and Schneider, A.-M. (2010), "Usage of public corporate communications of social responsibility in Brazil, Russia, India and China (BRIC)", International Journal of Emerging Markets, Vol. 5 No. 1, pp. 6-22.

4) Amaeshi, K. and Amao, O.O. (2009), "Corporate social responsibility in transnational spaces: exploring influences of varieties of capitalism on expressions of corporate codes of conduct in Nigeria", Journal of Business Ethics, Vol. 86 No. 2, pp. 225-239.

5) Carroll, A.B. (1991), "The pyramid of corporate social responsibility: toward the moral management of organizational stakeholders", Business Horizons, Vol. 34 No. 4, p. 39.

6) Eweje, G. (2007), "Multinational oil companies' CSR initiatives in Nigeria: the scepticism of stakeholders in host communities", Managerial Law, Vol. 49 Nos 5/6, pp. 218-235.

7) Gao, Y. (2009), "Corporate social responsibility and consumers' response: the missing linkage", Baltic Journal of Management, Vol. 4 No. 3, pp. 269-287.

8) Jones, P., Comfort, D. and Hillier, D. (2007), "Corporate social responsibility: a case study of the top ten global retailers", EuroMed Journal of Business, Vol. 2 No. 1, pp. 23-35.

9) Joshi, P.L. and Gao, S.S. (2009), "Multinational corporations' corporate social and environmental disclosures (CSED) on web sites", International Journal of Commerce and Management, Vol. 19
No. 1, pp. 27-44

10) Kolk, A. and Lenfant, F. (2009), "MNC reporting on CSR and conflict in Central Africa", Journal of Business Ethics, No. 93, pp. 241-255, ISSN: 01674544 (Print) 1573-0697 (Online, http:/ / www.springerlink.com).

11) Lee, K.-H. and Shin, D. (2010), "Consumers' responses to CSR activities: the linkage between increased awareness and purchase intention", Public Relations Review, Vol. 36 No. 2, pp. 193195.

12) Narwal, M. (2007), "CSR initiatives of Indian banking industry", Social Responsibility Journal, Vol. 3 No. 4, pp. 49-60.

13) Planken, B., Sahu, S. and Nickerson, C. (2010), "Corporate social responsibility communication in the Indian context", Journal of Indian Business Research, Vol. 2 No. 1, pp. 10-22.

14) Prout, J. (2006), "Corporate responsibility in the global economy: a business case", Society and Business Review, Vol. 1 No. 2, pp. 184-191.

15) Sachdeva, R. (2010), "Triple bottom line- a step ahead on the way of corporate social responsibility", Prabandhan: Indian Journal of Management, Vol. 3 No. 12, pp. 39-43.

16) Samy, M., Odemilin, G. and Bampton, R. (2010), "Corporate social responsibility: a strategy for sustainable business success. An analysis of 20 selected British companies", Corporate Governance, Vol. 10 No. 2, pp. 203-217.

17) Schneider, J.L., Wilson, A. and Rosenbeck, J.M. (2010), "Pharmaceutical companies and sustainability: an analysis of corporate reporting", Benchmarking: An International Journal, Vol. 17 No. 3, pp. 421-434.

18) Silberhorn, D. and Warren, R.C. (2007), "Defining corporate social responsibility: a view from big companies in Germany and the UK", European Business Review, Vol. 19 No. 5, pp. 352-372.

19) Tan, J. (2009), "Institutional structure and firm social performance in transitional economies: evidence of multinational corporations in China", Journal of Business Ethics, Vol. 86 No. 2, pp. 171-189. 
20) Wigley, S. (2008), "Gauging consumers' responses to CSR activities: does increased awareness make cents?", Public Relations Review, Vol. 34 No. 3, pp. 306-308.

21) Yang, X. and Rivers, C. (2009), "Antecedents of CSR practices in MNCs'subsidiaries: a stakeholder and institutional perspective", Journal of Business Ethics, Vol. 86 No. 2, pp. 155169.

22) Yoon, Y., Gu'rhan-Canli, Z. and Schwarz, N. (2006), "The effect of corporate social responsibility (CSR) activities on companies with bad reputations", Journal of Consumer Psychology, Vol. 16 No. 4, pp. 377-390. 